\title{
Disclaimer:
}

This PDF document is a pre-print version of the manuscript that was subsequently peer-reviewed and accepted for publication by the journal BioEnergy Research (Vol. 12, pages 1000-1011, year 2019). The final publication is available at Springer via https://doi.org/10.1007/s12155-019-10016-7.

\section{Tomato waste from processing industries as a feedstock for biofuel production}

\author{
María Hijosa-Valsero ${ }^{a^{*}}$, Jerson Garita-Cambroneroa ${ }^{a}$ Ana I. Paniagua-García ${ }^{a b}$, Rebeca Díez Antolínez ${ }^{\text {ab }}$
}

a Center of Biofuels and Bioproducts, Instituto Tecnológico Agrario de Castilla y León (ITACyL), Polígono Agroindustrial del Órbigo p. 2-6, E-24358, Villarejo de Órbigo, León, Spain

b Chemical and Environmental Bioprocess Engineering Group, Natural Resources Institute (IRENA), University of León, Avda. de Portugal 41, E- 24009, León, Spain

${ }^{*}$ Corresponding author

María Hijosa-Valsero, E-mail: hijvalma@itacyl.es

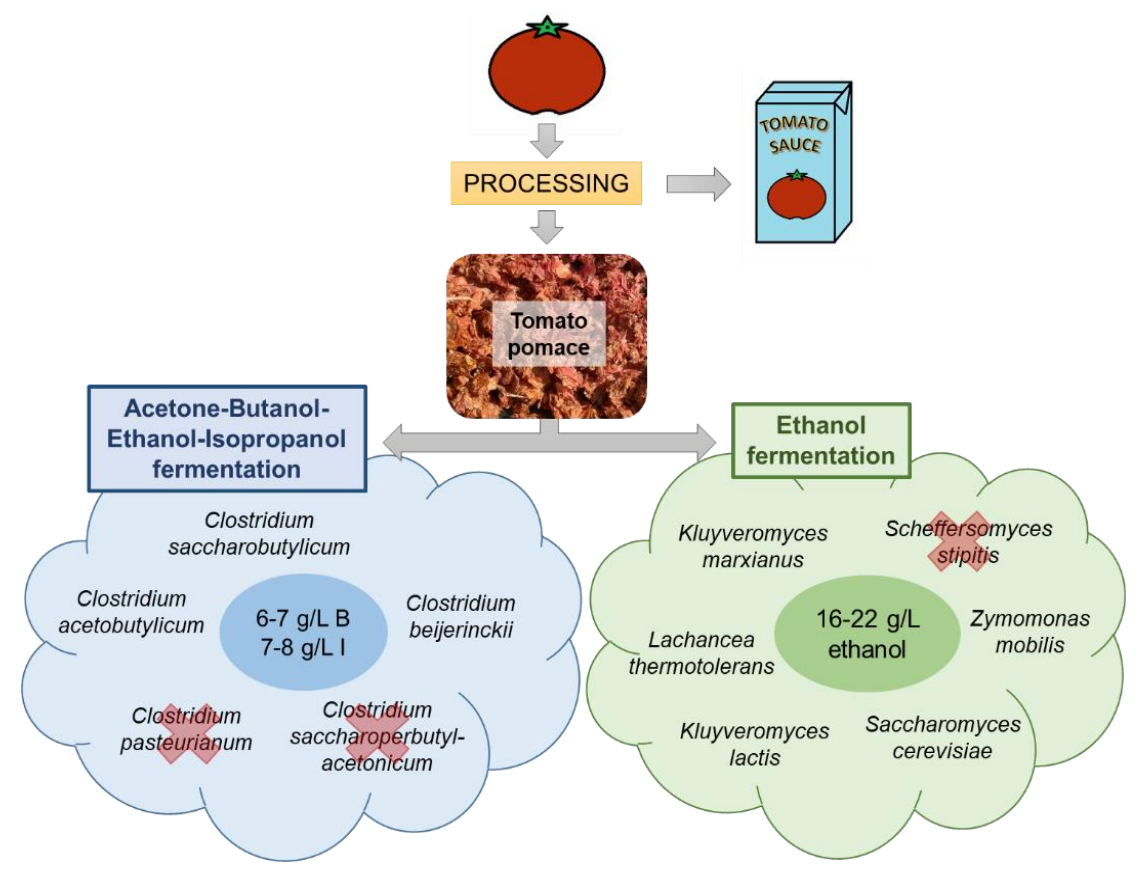

\begin{abstract}
Tomato pomace, a solid by-product of tomato processing industries, was assessed for the first time as a feedstock for acetone-butanol-ethanol-isopropanol (ABEI) fermentation. After pretreatment with autohydrolysis and enzymatic hydrolysis, a broth containing $44.1 \mathrm{~g} / \mathrm{L}$ total sugars was obtained. Twelve Clostridium strains were compared to find an appropriate microorganism for the transformation of tomato pomace hydrolysate. $C$. acetobutylicum DSM 792 produced $6.20 \pm 0.63 \mathrm{~g} / \mathrm{L}$ butanol and $8.28 \pm 0.85 \mathrm{~g} / \mathrm{L}$ isopropanol, whereas C. beijerinckii DSM 6423 produced $6.52 \pm 0.17 \mathrm{~g} / \mathrm{L}$ butanol and $7.30 \pm 0.23 \mathrm{~g} / \mathrm{L}$ isopropanol. In addition, another hydrolysate with a higher total sugar content $(85.1 \mathrm{~g} / \mathrm{L})$ was prepared and employed for bioethanol production by comparing twelve different yeast and bacterial strains. Kluyveromyces marxianus DSM 5422, Saccharomyces cerevisiae Ethanol Red ${ }^{\circledR}, S$. cerevisiae Hércules and Lachancea thermotolerans DSM 3434 produced 20.1-21.7 g/L ethanol. According to these results, tomato pomace could be an interesting feedstock for ABEl biorefineries.
\end{abstract}

Keywords: tomato waste; lignocellulosic biomass; butanol; ethanol; isopropanol 


\section{Introduction}

Nowadays, in an environmentally challenging context, it is necessary to explore and develop research that permits to tackle certain problems, such as greenhouse emissions, management of landfill wastes and the assurance of the food supply to a growing human population. Within this situation, the improvement in waste treatment during the foodchain production is mandatory in order to reduce its environmental repercussion (Otles and Kartal, 2018). Over recent years, the idea of a biorefinery concept has emerged as an approach to deal with waste management problems by converting agricultural and food processing wastes into high-valued compounds such as alcohols (butanol, ethanol and isopropanol) that can be utilised by bioenergetic or chemical industries (Hassan et al., 2019).

In the context of tomato agriculture, worldwide production reached $182 \mathrm{Mt}$ in 2017, with a total surface of $4.84 \cdot 10^{6}$ ha devoted to this crop (FAO, 2019). That same year, about $5.16 \mathrm{Mt}$ tomato were harvested in Spain, of which $58.13 \%$ were destined to the processing industry (Eurostat, 2019). According to Shrestha et al. (2016), a kilogram of processed tomatoes generates $20 \mathrm{~g}$ of discarded tomatoes and $20 \mathrm{~g}$ of tomato pomace, whereas del Valle et al. (2006) indicated that tomato pomace could represent at most $4 \%$ of the total fruit weight processed. Tomato pomace is the solid waste generated during the processing of tomatoes to obtain tomato juice, paste, sauce, puree or ketchup (Lenucci et al., 2013). The wet pomace contains $33 \%$ seed, $27 \%$ skin and $40 \%$ pulp while the dried pomace contains $44 \%$ seed and $56 \%$ pulp and skin (Kaur et al., 2008). The chemical composition of tomato pomace is variable depending on the sample analysed, but it is normally in the range of $10-18 \%$ starch, $27-32 \%$ cellulose, 5$18 \%$ hemicellulose, $11-26 \%$ simple sugars, $7.6 \%$ pectin, 31\% lignin, $12-23 \%$ protein, $5-20 \%$ fat and $4-$ $6 \%$ ash (del Valle et al., 2006; Hegde et al., 2018; Scoma et al., 2016; Singh et al., 2012). Tomato waste contains important amounts of $\mathrm{Ca}, \mathrm{K}(\sim 7-11 \mathrm{~g} / \mathrm{kg})$, $\mathrm{Mg}, \mathrm{Na}$ and $\mathrm{P}(\sim 2-3 \mathrm{~g} / \mathrm{kg})$, and lower amounts of $\mathrm{Fe}$, $\mathrm{Mn}$ and $\mathrm{Cu}$ (15-30 mg/kg) (Scoma et al., 2016).

Tomato pomace has been used mostly as animal feed (Hegde et al., 2018), but recently it has been proposed as a source of bioproducts, like polysaccharides (Tommonaro et al., 2008), lycopene, $\beta$-carotene, phenolic compounds, flavonoids, levulinic acid, phytosterols, vegetal oil, cutin (Fritsch et al., 2017; Ravindran and Jaiswal, 2016; Scoma et al., 2016) and as plant fertiliser or microbial growth medium
(Fritsch et al., 2017). The generation of biofuels like ethanol and butanol from a substantial number of lignocellulosic and food processing wastes has been extensively assessed (Diaz et al., 2018; Hijosa-Valsero et al., 2018a, 2018b; Huzir et al., 2018). However, the application of tomato waste in biofuel production by fermentation is not well studied (Hegde et al., 2018), in spite of the recent methods described to release simple sugars from tomato by-products (Díaz et al., 2017). So far, bioethanol production from tomato wastes has yielded poor results (Aramrueang et al., 2017; Kasavi et al., 2012; Lenucci et al., 2013; Patle and Lal, 2007). On the other hand, to the best of our knowledge, no information about biobutanol production from tomato pomace has been published yet.

In this work, tomato pomace was subjected to a soft pretreatment including autohydrolysis to release its fermentable sugars and obtain a liquid hydrolysate. The suitability of this hydrolysate as a feedstock for butanol production by acetone-butanol-ethanolisopropanol (ABEI) fermentation and for ethanol production by alcoholic fermentation was assessed with twenty-four different bacterial and yeast strains.

\section{Material and Methods}

\subsection{Tomato waste description}

Wet tomato wastes from a processing industry were provided by Conservas Vegetales de Extremadura S.A. (Badajoz, Spain) in August 2018. The raw biomass was dried in the open air during six days and then dried further in an oven at $45{ }^{\circ} \mathrm{C}$ during $48 \mathrm{~h}$. The dried biomass was ground in a rotary mill SM100 Comfort (Retsch GmbH, Haan, Germany) and kept in an airtight container until use.

The chemical characterisation of dry tomato waste was performed as described elsewhere (HijosaValsero et al., 2017). It was composed of $30.6 \%$ total carbohydrates (1.46\% soluble carbohydrates, $16.05 \%$ glucan and $11.27 \%$ hemicellulose), $5.27 \%$ galacturonic acid, $24.62 \%$ Klason lignin, $17.88 \%$ protein, $4.42 \%$ fat, $5.13 \%$ ash and $6.25 \%$ moisture. Its content of total phenolic compounds was $20.5 \mathrm{mg} / \mathrm{g}$, expressed as gallic acid equivalents (GAE).

\subsection{Hydrolysis of tomato waste}

In order to obtain sugar-rich fermentable hydrolysates, tomato waste was pretreated by autohydrolysis (i.e. using water as the only solvent and reagent). For the experiments of $A B E I$ fermentation, the biomass was pretreated in a high- 
pressure 2-L reactor made of alloy Carpenter 20 (Parr Instrument Company, Moline, IL, USA) at $121^{\circ} \mathrm{C}$ during $20 \mathrm{~min}$, with a solid-to-solvent ratio of $20 \%$ $(w / w)$. The total mass introduced in the reactor vessel for each batch was $400 \mathrm{~g}$. For the experiments of ethanol fermentation, the biomass was pretreated in an autoclave at $121^{\circ} \mathrm{C}$ during $20 \mathrm{~min}$, with a solid-tosolvent ratio of $30 \%(\mathrm{w} / \mathrm{w})$. It was necessary to employ a greater biomass load in the case of ethanol experiments $(30 \%)$ in order to guarantee a hydrolysate with a higher initial concentration of simple sugars, which is essential for a profitable ethanol fermentation process.

The samples were cooled down and then the solid/liquid mixture was subjected to enzymatic hydrolysis at pH 5.0 (citrate buffer $50 \mathrm{mM}$ ), $50{ }^{\circ} \mathrm{C}$ and $180 \mathrm{rpm}$ in an orbital shaker (HT Minitron, Infors AG, Bottmingen, Switzerland), by addition of $36 \mu \mathrm{l}$ Cellic CTec2 (activity $100 \mathrm{FPU} / \mathrm{mL}$; Novozymes, Tianjin, China) and $10 \mu \mathrm{l}$ Viscozyme L (activity $41 \mathrm{CMC} / \mathrm{mL}$; Novozymes, Bagsvaerd, Denmark) per $1 \mathrm{~g}$ of initial solid biomass. The hydrolysis time was set at $48 \mathrm{~h}$ or $120 \mathrm{~h}$, depending on the biomass load (20\% or $30 \%$, respectively).

The hydrolysates of the different batches were mixed and homogenised to guarantee the same initial composition of all the samples. These hydrolysates were directly employed (without filtration) in fermentation experiments.

\subsection{Biobutanol production}

Twelve bacterial strains were compared for their performance in tomato waste fermentation. The strains Clostridium acetobutylicum DSM 792, DSM 6228, C. beijerinckii DSM 51, DSM 552, DSM 791, DSM 1820, DSM 6423, C. pasteurianum DSM 526, C. saccharobutylicum DSM 13864, C. saccharoperbutylacetonicum DSM 2152 and DSM 14923 were purchased from DSMZ (Braunschweig, Germany), whereas the strain C. beijerinckii CECT 508 was supplied by CECT (Paterna, Spain). Seed cultures for fermentation were prepared from stocks of pure spore solutions of each strain maintained at $4{ }^{\circ} \mathrm{C}$ in sterile distilled water. These spores were heatactivated in reinforced clostridial medium (RCM) broth or in the case of strains DSM 2152 and DSM 792 in a potato-based medium (Yerushalmi and Volesky, 1987) as described previously (PaniaguaGarcía et al., 2018). Inocula from the non-spore forming strain DSM 6228 were performed by using a single bacterial colony from a $48 \mathrm{~h} \mathrm{RCM} \mathrm{plate} \mathrm{culture}$ ( $2 \%$ agar) obtained from a bacterial stock maintained at $-80{ }^{\circ} \mathrm{C}$ in glycerol $(80 \% \mathrm{v} / \mathrm{v})$. Liquid inocula were maintained at $35^{\circ} \mathrm{C}$ until reaching a cell density of $5 \cdot 10^{8}$ cells $/ \mathrm{mL}(24-48 \mathrm{~h})$ as determined by counting in a Bürker chamber (Paul Marienfeld GmbH \& Co. KG, Lauda-Königshofen, Germany).

For fermentation experiments, $50 \mathrm{~mL}$ of tomato hydrolysates were placed in $100-\mathrm{mL}$ glass bottles, where $5 \mathrm{~g} / \mathrm{L}$ yeast extract, $2.1 \mathrm{~g} / \mathrm{L} \mathrm{NH}_{4} \mathrm{Cl}, 1 \mathrm{~g} / \mathrm{L}$ $\mathrm{KH}_{2} \mathrm{PO}_{4}$ and $5 \mathrm{~g} / \mathrm{L} \mathrm{CaCO}_{3}$ were added. The bottles were sterilised at $121^{\circ} \mathrm{C}$ for $15 \mathrm{~min}$ and, after adding $0.01 \mathrm{~g} / \mathrm{L} \mathrm{FeSO}_{4} \cdot 7 \mathrm{H}_{2} \mathrm{O}, 0.2 \mathrm{~g} / \mathrm{L} \mathrm{MgSO}_{4} \cdot 7 \mathrm{H}_{2} \mathrm{O}$ and 0.5 $\mathrm{g} / \mathrm{L}$ cysteine, the $\mathrm{pH}$ was adjusted to 6.0 with a solution of $\mathrm{NaOH} 40 \%$. The bottles were closed in an airtight manner with rubber caps and they were inoculated with $3 \%(\mathrm{v} / \mathrm{v})$ of the corresponding bacterial strain. Gaseous $\mathrm{N}_{2}$ was bubbled into the bottom of the sample for $5 \mathrm{~min}$ to guarantee anaerobic conditions. Then, the bottles were incubated at $35^{\circ} \mathrm{C}$ and $100 \mathrm{rpm}$ during $96 \mathrm{~h}$ in an orbital shaker (Infors HT Minitron, Infors AG, Bottmingen, Switzerland). Control fermentations were carried out for all the strains, with an aqueous solution containing glucose and xylose mixtures at similar concentrations to those of tomato hydrolysates (37 g/L glucose and $12 \mathrm{~g} / \mathrm{L}$ xylose) and the abovementioned nutrients. All experiments were performed in triplicate.

\subsection{Production of ethanol}

\subsubsection{Strain cultivation and inocula preparation}

Twelve different bacterial and yeast strains were compared for ethanol production. Kluyveromyces lactis var. lactis DSM 70799, K. marxianus DSM 5422, K. marxianus DSM 5418, K. marxianus DSM 7239, $K$. thermotolerans DSM 3434 (currently classified as Lachancea thermotolerans), Saccharomyces cerevisiae DSM 70449, Scheffersomyces stipitis DSM 3651, S. stipitis DSM 3652 and Zymomonas mobilis DSM 3580 were provided by DSMZ (Braunschweig, Germany); $S$. cerevisiae Ethanol $\operatorname{Red}^{\circledast}$ was obtained from Lesaffre Advanced Fermentations (Marcq-en-Baroeul, France); S. cerevisiae Hércules-green was provided by Lesaffre Ibérica S.A. (Valladolid, Spain); and S. cerevisiae CECT 1383 was purchased from CECT (Paterna, Spain).

Yeast strains, from a cryopreserved solution (glycerol $80 \% \mathrm{v} / \mathrm{v})$, were inoculated on culture plates $(10 \mathrm{~g} / \mathrm{L}$ glucose, $3 \mathrm{~g} / \mathrm{L}$ yeast extract , $3 \mathrm{~g} / \mathrm{L}$ malt extract, $5 \mathrm{~g} / \mathrm{L}$ soy peptone, $20 \mathrm{~g} / \mathrm{L}$ agar) and maintained at $20{ }^{\circ} \mathrm{C}$ until obtaining colonies of 1-2 mm. Subsequently, seed cultures for fermentation were prepared in liquid medium from a single yeast colony and kept at 
$30{ }^{\circ} \mathrm{C}$ and $150 \mathrm{rpm}$ during the time necessary to reach a concentration of $1 \cdot 10^{8}$ cells $/ \mathrm{mL}$ (incubation time varied from 7-24 $\mathrm{h}$ depending of the strain used, with the exception of strain DSM 3434 which required 48 h). In the case of $Z$. mobilis DSM 3580, cryopreserved stock solutions were cultured as described previously (Silbir et al., 2014) during $24 \mathrm{~h}$. Then, a single colony was inoculated in $50 \mathrm{~mL}$ of liquid medium in a 100-mL glass bottle capped with a rubber stopper in anaerobic conditions by injecting gaseous nitrogen in the headspace during $5 \mathrm{~min}$. The inoculum was kept $24 \mathrm{~h}$ at $30{ }^{\circ} \mathrm{C}$ (cell density $1 \cdot 10^{8}$ cells $/ \mathrm{mL}$ ). For all strains, cell density was determined by using a Bürker counting chamber (Paul Marienfeld GmbH \& Co. KG, Lauda-Königshofen, Germany).

\subsubsection{Alcoholic fermentation}

Tomato waste hydrolysate was not sterilised and it was not supplemented with any nutrients. Its $\mathrm{pH}$ was adjusted to 5.0 with $\mathrm{NaOH}$ and it was inoculated with $3 \%(\mathrm{v} / \mathrm{v})$ of liquid inoculum containing yeasts or bacteria. All yeast fermentations were performed in 100-mL Erlenmeyer flasks containing $50 \mathrm{~mL}$ tomato hydrolysate, plugged with foam stoppers, under aerobic conditions. Fermentations with $Z$. mobilis DSM 3580 were carried out in 100-mL rubber-capped bottles containing $50 \mathrm{~mL}$ tomato waste, where gaseous $\mathrm{N}_{2}$ was bubbled during $5 \mathrm{~min}$ to guarantee anaerobic conditions. Fermentation controls were prepared with aqueous solutions at $\mathrm{pH} 5.0$ containing glucose and xylose mixtures at similar concentrations to those of tomato hydrolysates $(60 \mathrm{~g} / \mathrm{L}$ glucose, 22 $\mathrm{g} / \mathrm{L}$ xylose), and supplemented with nutrients and salts $\left(10.4 \mathrm{~g} / \mathrm{L}\right.$ yeast extract and $1.47 \mathrm{~g} / \mathrm{L} \mathrm{KH}_{2} \mathrm{PO}_{4}$ for yeasts; and $7 \mathrm{~g} / \mathrm{L}$ yeast extract, $2.5 \mathrm{~g} / \mathrm{L} \mathrm{K}_{2} \mathrm{HPO}_{4}, 1.6$ $\mathrm{g} / \mathrm{L}\left(\mathrm{NH}_{4}\right)_{2} \mathrm{SO}_{4}$ and $1 \mathrm{~g} / \mathrm{L} \mathrm{MgSO} 4 \cdot 7 \mathrm{H}_{2} \mathrm{O}$ for bacteria). All samples and controls were fermented in triplicate in an orbital shaker at $30^{\circ} \mathrm{C}$ and $150 \mathrm{rpm}$ during $72 \mathrm{~h}$.

\subsection{Chemical analyses}

Samples of hydrolysates and fermented broths were centrifuged, filtered and analyzed according to Hijosa-Valsero et al. (2017) for the quantification of sugars (cellobiose, maltose, glucose, xylose, galactose, mannose, rhamnose and arabinose), potential fermentation inhibitors (formic acid, acetic acid, levulinic acid, 5-hydroxymethylfurfural (5-HMF) and furfural) and fermentation products (acetone, butanol, ethanol, isopropanol, acetic acid and butyric acid). Butanol and ethanol fermentation yields $\left(Y_{B / S}\right.$, $\left.\mathrm{Y}_{\mathrm{E} / \mathrm{S}}\right)$ and productivities $\left(\mathrm{W}_{\mathrm{B} / \mathrm{S}}, \mathrm{W}_{\mathrm{E} / \mathrm{S}}\right)$ were calculated as reported by Hijosa-Valsero et al. (2017), based on total sugar consumption.

\subsection{Statistical analyses}

Samples were compared with a one-way ANOVA and Tukey's HSD test using the software Statistica 7 (StatSoft Inc., Tulsa, OK, USA).

\section{Results and discussion}

\subsection{Hydrolysis of tomato waste}

High solvent-to-solid ratios were employed during the pretreatment $(20-30 \%$ biomass, w/w) in order to guarantee a sufficient sugar concentration in the hydrolysate for fermentations, since the total carbohydrate content of dry tomato waste was relatively low (30.6\% carbohydrates). It was observed that the enzymatic hydrolysis step was slowed down and prolonged from 48 to $120 \mathrm{~h}$ when increasing the solid biomass load from 20 to $30 \% \mathrm{w} / \mathrm{w}$. Therefore, the hydrolysis of the samples destined for $\mathrm{ABEI}$ fermentation ( $20 \%$ solid load) was faster than that of the samples prepared for ethanol fermentation $(30 \%$ solid load).

Table 1. Chemical composition ( $\mathrm{g} / \mathrm{L})$ of tomato waste hydrolysates.

\begin{tabular}{|l|l|l|}
\hline Compound & $\begin{array}{l}\text { Biomass } \\
20 \% \quad \text { (for } \\
\text { ABEI } \\
\text { fermentation) }\end{array}$ & $\begin{array}{l}\text { Biomass } \\
30 \% \quad \text { (for } \\
\text { ethanol } \\
\text { fermentation) }\end{array}$ \\
\hline Cellobiose + Maltose & $<0.05$ & $<0.05$ \\
\hline Glucose & $31.4 \pm 1.0$ & $56.0 \pm 1.3$ \\
\hline $\begin{array}{l}\text { Xylose + Mannose + } \\
\text { Galactose }\end{array}$ & $9.3 \pm 1.6$ & $22.0 \pm 1.0$ \\
\hline Rhamnose & $3.2 \pm 0.3$ & $5.7 \pm 0.3$ \\
\hline Arabinose & $0.3 \pm 0.1$ & $0.94 \pm 0.14$ \\
\hline Total sugars & $44.1 \pm 3.0$ & $84.6 \pm 2.5$ \\
\hline Formic acid & $0.23 \pm 0.08$ & $0.36 \pm 0.04$ \\
\hline Acetic acid & $1.64 \pm 0.06$ & $2.79 \pm 0.06$ \\
\hline Levulinic acid & $<0.02$ & $0.11 \pm 0.01$ \\
\hline 5-HMF & $<0.02$ & $<0.02$ \\
\hline Furfural & $<0.02$ & $0.06 \pm 0.01$ \\
\hline
\end{tabular}

The chemical composition of tomato waste hydrolysates is shown in Table 1 . The broth used for ABEl fermentation contained $44.1 \mathrm{~g} / \mathrm{L}$ total sugars, which implies the release of $58.5 \%$ of the carbohydrates present in tomato waste biomass. On the other hand, the broth prepared for ethanol fermentation was composed of $85.1 \mathrm{~g} / \mathrm{L}$ total sugars, entailing a carbohydrate release efficiency of $66.6 \%$. Other tomato pomace hydrolysates reported in 
literature and destined for ethanol fermentation contained 36-57 g/L total sugar (Lenucci et al., 2013; Patle and Lal, 2007). Therefore, the applied pretreatment in the present work was efficient for sugar release. In fact, autohydrolysis, followed by enzymatic hydrolysis, has been proven as an efficient pretreatment for tomato wastes (del Campo et al., 2006; Díaz et al., 2017).

Regarding the generation of fermentation inhibitors, only formic acid (0.23-0.36 g/L) and acetic acid (1.64$2.79 \mathrm{~g} / \mathrm{L})$ exhibited relevant values, especially in the case of the hydrolysate allocated to ethanol fermentation (Table 1). Levulinic acid, 5-HMF and furfural were present at very low concentrations.

\subsection{Biobutanol production from tomato waste}

Some of the tested strains produced acetone (A), butanol (B) and ethanol (E) as main solvents, whereas other strains transformed part of the acetone into isopropanol (I), according to their typical metabolic pathways (Chen et al., 2013). The highest acetone production was achieved by C. saccharobutylicum DSM 13864 (5.95 $\pm 0.36 \mathrm{~g} / \mathrm{L}$ acetone), the best butanol concentration was obtained by $C$. beijerinckii DSM $1820(7.00 \pm 0.05 \mathrm{~g} / \mathrm{L}$ butanol), whereas the greatest isopropanol value was provided by $C$. acetobutylicum DSM $792 \quad(8.28 \quad \pm \quad 0.85 \quad \mathrm{~g} / \mathrm{L}$ isopropanol) (Table 2). Ethanol concentrations were below $1 \mathrm{~g} / \mathrm{L}$ for all the tested strains. Regarding the total production of solvents (sum of concentrations, ABEI), the strains C. acetobutylicum DSM 792 and C. beijerinckii DSM 6423 were significantly superior to the rest of strains $(p<0.05)$, attaining concentrations of 14.5-15.1 g/L ABEl (Table 2). On the other hand, some strains, such as C. beijerinckii CECT 508, DSM 51, DSM 552, DSM 791, C. pasteurianum DSM 526, C. saccharoperbutylacetonicum DSM 2152 and DSM 14923, were unable to properly ferment tomato pomace (Table 2). Although isopropanol concentration was slightly higher for $C$. acetobutylicum DSM 792 than for C. beijerinckii DSM 6423 ( $p<0.05$ ), the fermentation broths of the former were difficult to handle during the posterior analytical procedures due to their gelatinous nature. This fact should be taken into account for potential industrial applications.

It must be noted that the isopropanol:butanol ratio of the two abovementioned strains (DSM 792 and DSM 6423) was remarkably high for the fermentation of tomato wastes (A:B:E:I was approximately 1:28:1.6:38 for DSM 792, and 1:24:1.4:27 for DSM 6423), a fact which could be related to the chemical composition of tomato pomace hydrolysate. In fact, isopropanol:butanol ratios were clearly lower in the case of control fermentations of simple synthetic media (Table A1). It has been observed that the acetone:butanol ratio in C. acetobutylicum can vary depending on the nutrient composition of the fermentation medium (mainly iron and phosphorus) and on fermentation conditions like pH (Bahl et al., 1986). In addition, the ratios of isopropanol:acetone are affected by the concentrations of acetate, butyrate and vitamin B3 (Xin et al., 2017).

Table 2. Parameters of ABEl fermentation for tomato pomace hydrolysates. Note: Superscripts (a, b, $c$, etc.) represent statistical differences among strains $(p<0.05)$. If two strains share at least one letter for a given column, they do not differ significantly.

\begin{tabular}{|c|c|c|c|c|c|c|c|c|c|c|c|}
\hline Species & Strain & $A(g / L)$ & $B(g / L)$ & $E(g / L)$ & $\mathrm{I}(\mathrm{g} / \mathrm{L})$ & $\begin{array}{l}\text { Acetate } \\
(\mathrm{g} / \mathrm{L})\end{array}$ & $\begin{array}{l}\text { Butyrate } \\
\text { (g/L) }\end{array}$ & $\begin{array}{l}\text { Sum ABEI } \\
(\mathrm{g} / \mathrm{L})\end{array}$ & $\begin{array}{l}\text { Total sugar } \\
\text { consumption } \\
(\%) \\
\end{array}$ & $Y_{B / S}(g / g)$ & $W_{B}[g /(L \cdot h)]$ \\
\hline C. acetobutylicum & DSM 792 & $\begin{array}{ll}0.22 & \pm \\
0.11 \text { bde } & \end{array}$ & $\begin{array}{l}6.20 \\
0.63^{\mathrm{eb}}\end{array}$ & $\begin{array}{ll}0.36 & \pm \\
0.09^{\text {ac }} & \end{array}$ & $\begin{array}{ll}8.28 & \pm \\
0.85^{b} & \end{array}$ & $\begin{array}{ll}2.92 & \pm \\
0.72 & \end{array}$ & $\begin{array}{ll}0.13 & \pm \\
0.04^{b} & \end{array}$ & $\begin{array}{ll}15.07 \\
1.33^{b}\end{array}$ & $70 \pm 8^{b}$ & $\begin{array}{ll}0.203 \\
0.009^{b}\end{array}$ & $\begin{array}{ll}0.065 & \pm \\
0.007^{b} & \end{array}$ \\
\hline C. beijerinckii & DSM 6423 & $\begin{array}{ll}0.27 & \pm \\
0.03^{\text {bde }} & \\
\end{array}$ & $\begin{array}{ll}6.52 & \pm \\
0.17^{\mathrm{eb}} & \end{array}$ & $\begin{array}{ll}0.39 & \pm \\
0.02^{c} & \\
\end{array}$ & $\begin{array}{ll}7.30 & \pm \\
0.23^{c} & \\
\end{array}$ & $\begin{array}{ll}4.72 & \pm \\
0.22 & \\
\end{array}$ & $\begin{array}{ll}0.45 & \pm \\
0.06^{\mathrm{b}} & \\
\end{array}$ & $\begin{array}{l}14.48 \\
0.07^{\mathrm{b}}\end{array}$ & $81 \pm 3^{a}$ & $\begin{array}{ll}0.184 & \pm \\
0.005^{\mathrm{ab}} & \end{array}$ & $\begin{array}{l}0.068 \\
0.006^{b}\end{array}$ \\
\hline C. beijerinckii & CECT 508 & $\begin{array}{ll}0.42 & \pm \\
0.22^{\text {bde }} & \end{array}$ & $\begin{array}{ll}0.48 & \pm \\
0.33^{\mathrm{d}} & \end{array}$ & $\begin{array}{ll}0.07 & \pm \\
0.00^{\text {bd }} & \end{array}$ & $<0.05^{a}$ & n.q. & $\begin{array}{ll}3.66 & \pm \\
0.18^{\mathrm{d}} & \end{array}$ & $\begin{array}{ll}0.97 & \pm \\
0.55^{\mathrm{d}} & \end{array}$ & $18 \pm 4^{\text {de }}$ & $\begin{array}{ll}0.066 & \pm \\
0.046^{\text {ef }} & \end{array}$ & $\begin{array}{l}0.005 \\
0.006^{\mathrm{d}}\end{array}$ \\
\hline C. beijerinckii & DSM 51 & $\begin{array}{ll}0.09 & \pm \\
0.01^{\text {bde }} & \end{array}$ & $\begin{array}{ll}2.35 & \pm \\
0.04^{\mathrm{c}} & \end{array}$ & $\begin{array}{ll}0.08 & \pm \\
0.01^{\mathrm{bd}} & \end{array}$ & $\begin{array}{ll}0.16 & \pm \\
0.00^{\mathrm{a}} & \end{array}$ & $\begin{array}{ll}5.46 & \pm \\
0.06 & \end{array}$ & $\begin{array}{ll}4.95 & \pm \\
0.19^{\mathrm{e}}\end{array}$ & $\begin{array}{ll}2.67 & \pm \\
0.02^{\text {cd }} & \end{array}$ & $59 \pm 2^{c}$ & $\begin{array}{l}0.097 \quad \pm \\
0.003^{\text {cef }}\end{array}$ & $\begin{array}{l}0.024 \\
0.006^{c}\end{array}$ \\
\hline C. beijerinckii & DSM 552 & $\begin{array}{ll}0.08 & \pm \\
0.00^{\mathrm{d}} & \\
\end{array}$ & $\begin{array}{ll}0.51 & \pm \\
0.03^{\mathrm{d}} & \\
\end{array}$ & $\begin{array}{ll}0.07 & \pm \\
0.01^{\mathrm{bd}} & \\
\end{array}$ & $\begin{array}{ll}0.14 & \pm \\
0.01^{\mathrm{a}} & \\
\end{array}$ & n.q. & $\begin{array}{ll}4.09 & \pm \\
0.63^{\mathrm{de}} & \end{array}$ & $\begin{array}{ll}0.80 & \pm \\
0.05^{d} & \\
\end{array}$ & $32 \pm 0^{f}$ & $\begin{array}{ll}0.038 & \pm \\
0.001^{f} & \\
\end{array}$ & $\begin{array}{l}0.005 \\
0.006^{d}\end{array}$ \\
\hline C. beijerinckii & DSM 791 & $\begin{array}{ll}0.67 & \pm \\
0.27^{\mathrm{e}} & \\
\end{array}$ & $\begin{array}{ll}1.02 & \pm \\
0.45^{d} & \end{array}$ & $\begin{array}{ll}0.06 & \pm \\
0.01^{\text {bd }} & \end{array}$ & $<0.05^{a}$ & n.q. & $\begin{array}{ll}1.61 & \pm \\
0.14^{\text {ac }} & \\
\end{array}$ & $\begin{array}{ll}1.75 & \pm \\
0.73^{\mathrm{d}} & \\
\end{array}$ & $21 \pm 7^{\text {de }}$ & $\begin{array}{ll}0.115 & \pm \\
0.030^{\text {ce }} & \\
\end{array}$ & $\begin{array}{l}0.011 \\
0.006^{d}\end{array}$ \\
\hline C. beijerinckii & DSM 1820 & $\begin{array}{ll}3.87 & \pm \\
0.45^{c} & \end{array}$ & $\begin{array}{ll}7.00 & \pm \\
0.05^{\mathrm{b}} & \end{array}$ & $\begin{array}{ll}0.17 & \pm \\
0.01^{\text {bdg }} & \end{array}$ & $<0.05^{a}$ & $\begin{array}{ll}4.36 & \pm \\
0.08 & \end{array}$ & $\begin{array}{ll}1.90 & \pm \\
0.33^{\text {ac }} & \end{array}$ & $\begin{array}{ll}11.03 & \pm \\
0.51^{\mathrm{ae}} & \end{array}$ & $81 \pm 13^{\mathrm{ab}}$ & $\begin{array}{ll}0.209 & \pm \\
0.011^{\mathrm{b}} & \\
\end{array}$ & $\begin{array}{l}0.073 \\
0.006^{b}\end{array}$ \\
\hline C. pasteurianum & DSM 526 & $\begin{array}{l}0.14 \quad \pm \\
0.05^{\text {bde }}\end{array}$ & $\begin{array}{l}2.60 \\
0.26^{c}\end{array} \quad \pm$ & $\begin{array}{l}0.13 \\
0.01^{\text {bdf }}\end{array}$ & $\begin{array}{l}1.52 \quad \pm \\
0.21^{\mathrm{d}}\end{array}$ & n.q. & $\begin{array}{ll}2.38 & \pm \\
0.48^{\mathrm{c}} & \end{array}$ & $\begin{array}{ll}4.38 & \pm \\
0.48^{\mathrm{c}} & \end{array}$ & $54 \pm 2^{c}$ & $\begin{array}{l}0.111 \\
0.017^{\text {cde }}\end{array} \pm$ & $\begin{array}{l}0.027 \\
0.006^{c}\end{array}$ \\
\hline C. saccharobutylicum & DSM 13864 & $\begin{array}{ll}5.95 & \pm \\
0.36^{\mathrm{a}} & \\
\end{array}$ & $\begin{array}{ll}5.82 & \pm \\
0.26^{\mathrm{ae}} & \\
\end{array}$ & $\begin{array}{ll}0.22 & \pm \\
0.02^{\text {afg }} & \\
\end{array}$ & $<0.05^{a}$ & n.q. & $\begin{array}{ll}1.07 & \pm \\
0.16^{\mathrm{ab}} & \\
\end{array}$ & $\begin{array}{ll}11.99 & \pm \\
0.63^{\mathrm{a}} & \\
\end{array}$ & $86 \pm 0^{a}$ & $\begin{array}{ll}0.144 & \pm \\
0.006^{\mathrm{ac}} & \\
\end{array}$ & $\begin{array}{ll}0.061 & \pm \\
0.006^{\mathrm{ab}} & \end{array}$ \\
\hline C. saccharoperbutylacetonicum & DSM 2152 & $\begin{array}{ll}0.62 & \pm \\
0.06^{\text {bde }} & \\
\end{array}$ & $\begin{array}{ll}1.21 & \pm \\
0.14^{d} & \\
\end{array}$ & $\begin{array}{l}0.13 \pm \\
0.01^{\text {bdf }}\end{array}$ & $<0.05^{a}$ & n.q. & $\begin{array}{ll}2.10 & \pm \\
0.41^{\mathrm{c}} & \\
\end{array}$ & $\begin{array}{ll}1.96 & \pm \\
0.21^{\mathrm{d}} & \\
\end{array}$ & $24 \pm 1^{\text {def }}$ & $\begin{array}{ll}0.116 & \pm \\
0.003^{\text {ce }} & \\
\end{array}$ & $\begin{array}{ll}0.013 & \pm \\
0.006^{d} & \end{array}$ \\
\hline C. saccharoperbutylacetonicum & DSM 14923 & $\begin{array}{ll}0.45 & \pm \\
0.03^{\text {bde }} & \\
\end{array}$ & $\begin{array}{ll}0.61 & \pm \\
0.10^{d} & \end{array}$ & $\begin{array}{ll}0.09 & \pm \\
0.01^{\mathrm{d}} & \end{array}$ & $<0.05^{a}$ & n.q. & $\begin{array}{ll}1.98 & \pm \\
0.04^{\mathrm{ac}} & \end{array}$ & $\begin{array}{ll}1.15 & \pm \\
0.14^{d} & \\
\end{array}$ & $22 \pm 3^{e}$ & $\begin{array}{ll}0.065 & \pm \\
0.005^{\text {ef }} & \end{array}$ & $\begin{array}{l}0.006 \\
0.006^{d}\end{array}$ \\
\hline
\end{tabular}

n.q. Not quantified due to chromatographic interferences. 
Total sugar consumption varied between 18 and $86 \%$ depending on the strain (Table 2). Sugar consumption was related to a successful $A B E I$ fermentation. Actually, all the strains with a sugar consumption above 70\% (DSM 6228, DSM 6423, DSM 1820, DSM 13864, DSM 792) were able to produce at least $5 \mathrm{~g} / \mathrm{L}$ butanol. The highest butanol yields $\left(\mathrm{Y}_{\mathrm{B} / \mathrm{S}}\right)$ attained were about $0.20 \mathrm{~g} / \mathrm{g}$ (Table 2). This value is lower than the yields of $0.27 \mathrm{~g} / \mathrm{g}$ reported in literature for the fermentation of other food wastes like apple pomace or coffee silverskin (Hijosa-Valsero et al., 2017, 2018a), but similar to that of potato peel (Hijosa-Valsero et al., 2018b).

\subsection{Ethanol production from tomato waste}

The yeast and bacterial strains employed in this study for ethanol production differ in their abilities to ferment or assimilate various carbon sources (Table $3)$. The species $S$. stipitis, K. marxianus and $K$. lactis var. lactis have the potential to grow on a broad variety of carbohydrate substrates.

According to the results obtained in control fermentations, all the tested strains were capable of fermenting glucose/xylose mixtures (Table A2). However, not all of them were able to cope with tomato pomace hydrolysate. In this regard, the four best-performing strains for tomato samples were $K$. marxianus DSM 5422, S. cerevisiae Ethanol $\operatorname{Red}^{\circledR}, L$. thermotolerans DSM 3434 and S. cerevisiae Hércules, with ethanol values of 20.1-21.7 g/L (Table 4). Other strains like $K$. marxianus DSM 5418, K. marxianus 7239, K. lactis DSM 70799 and Z. mobilis DSM 3580 offered ethanol values above $16 \mathrm{~g} / \mathrm{L}$. On the contrary, the two strains of S. stipitis (DSM 3651, DSM 3652) were unable to ferment tomato pomace hydrolysate, in spite of their ability to assimilate and ferment numerous sugar sources (Table 3), a fact which could indicate their sensitivity to inhibitory compounds present in tomato hydrolysate. It has been reported that S. stipitis is less tolerant to inhibitors than $S$. cerevisiae (Olofsson et al., 2008). Bellido et al. (2011) observed that a concentration of $2.5 \mathrm{~g} / \mathrm{L}$ acetic acid caused an inhibition of $60 \%$ in growth and ethanol production in S. stipitis DSM 3651, a value similar to that of the tomato pomace hydrolysate (Table 1).

Total sugar consumption was $78-90 \%$ for all the yeasts that fermented tomato pomace successfully (Table 4). Nevertheless, the bacterial strain $Z$. mobilis DSM 3580 had a clearly lower $(p<0.05)$ sugar consumption, which could be related to its limited carbohydrate utilisation (Table 3).

According to metabolic stoichiometry, $1 \mathrm{~mol}$ of glucose produces $2 \mathrm{~mol}$ of ethanol, and $1 \mathrm{~mol}$ of xylose produces $1.6 \mathrm{~mol}$ of ethanol (or even $0.96 \mathrm{~mol}$ ethanol) (Pentjuss et al., 2017). This implies theoretical ethanol yields $\left(Y_{E}\right)$ of $0.511 \mathrm{~g} / \mathrm{g}$ for glucose and $0.294-0.491 \mathrm{~g} / \mathrm{g}$ for xylose. Under experimental conditions, the observed ethanol yields $Y_{E / S}$ for glucose:xylose mixtures are temperature-dependent and lie in the range of $0.37-0.49 \mathrm{~g} / \mathrm{g}$ (Rodrussamee et al., 2011). The ethanol yields based on total sugars $\left(Y_{E / S}\right)$ calculated in the present study are slightly lower than the abovementioned results; for instance, the four best-performing yeasts for tomato pomace hydrolysate obtained yields of $0.266-0.323 \mathrm{~g} / \mathrm{g}$ (Table 4).

Table 3. Carbohydrate sources fermented $(+)$ or assimilated $(A)$ by the strains tested for alcoholic fermentation.

\begin{tabular}{|l|c|c|c|c|c|c|c|c|c|c|c|c|c|c|l|l|}
\hline Species & Glu & Man & Fru & Suc & Mal & Gal & Lac & Raf & Tre & Xyl & Inu & Cel & Rha & Ara & Sta & References \\
\hline Lachancea thermotolerans & + & & & + & + & + & & + & + & & + & & & & & $\begin{array}{l}\text { Lachance and Kurtzman, } \\
2011\end{array}$ \\
\hline $\begin{array}{l}\text { Kluyveromyces lactis var. } \\
\text { lactis }\end{array}$ & + & & & + & + & + & + & + & + & A & A & A & & & & $\begin{array}{l}\text { Lachance, 2011; Lane et al., } \\
2011\end{array}$ \\
\hline Kluyveromyces marxianus & + & + & $\mathrm{A}$ & + & & + & + & + & & + & + & $\mathrm{A}$ & & $\mathrm{A}$ & & $\begin{array}{l}\text { Lachance, 2011; Lane et al., } \\
2011 ; \text { Pentjuss et al., 2017; } \\
\text { Rodrussamee et al., 2011 }\end{array}$ \\
\hline Saccharomyces cerevisiae & + & + & + & + & + & + & & + & $\mathrm{A}$ & & & & $\mathrm{A}$ & & & $\begin{array}{l}\text { van Maris et al., 2006; } \\
\text { Vaughan-Martini and Martini, } \\
2011\end{array}$ \\
\hline Scheffersomyces stipitis & + & + & & $\mathrm{A}$ & + & + & $\mathrm{A}$ & & + & + & & + & $\mathrm{A}$ & $\mathrm{A}$ & $\mathrm{A}$ & $\begin{array}{l}\text { du Preez et al., 1986; } \\
\text { Kurtzman, 2011 }\end{array}$ \\
\hline Zymomonas mobilis & + & & + & $\mathrm{A}$ & & & & & & & & & & & & $\begin{array}{l}\text { de Araújo et al., 2018; } \\
\text { Silveira and Jonas, 2002; } \\
\text { Sprenger, 1996 }\end{array}$ \\
\hline
\end{tabular}

Glu: glucose; Man: mannose; Fru: fructose; Suc: sucrose; Mal: maltose; Gal: galactose; Lac: lactose; Raf: raffinose; Tre: trehalose; Xyl: xylose; Inu: inulin; Cel: cellobiose; Rha: rhamnose; Ara: L-arabinose; Sta: Starch. 
Table 4. Alcoholic fermentation of tomato pomace hydrolysate. Note: Superscripts (a, b, c, etc.) represent statistical differences among strains $(p<0.05)$. If two strains share at least one letter for a given column, they do not differ significantly.

\begin{tabular}{|c|c|c|c|c|c|c|c|c|}
\hline Species & Strain & $\begin{array}{l}\text { Ethanol } \\
(\mathrm{g} / \mathrm{L})\end{array}$ & $\begin{array}{c}\text { Acetic acid } \\
(\mathrm{g} / \mathrm{L})\end{array}$ & $\begin{array}{l}\text { Lactic acid } \\
(\mathrm{g} / \mathrm{L})\end{array}$ & $\begin{array}{c}\text { Total sugar } \\
\text { consumption (\%) }\end{array}$ & $\begin{array}{c}\text { Glucose } \\
\text { consumption (\%) }\end{array}$ & $Y_{E / S}(g / g)$ & $W_{E}[g /(L \cdot h)]$ \\
\hline $\begin{array}{l}\text { Lachancea } \\
\text { thermotolerans }\end{array}$ & DSM 3434 & $\begin{array}{l}20.56 \pm \\
0.30 \text { cef }\end{array}$ & $\begin{array}{c}2.98 \pm \\
0.11^{\mathrm{a}} \\
\end{array}$ & $0.29 \pm 0.31$ & $78 \pm 1^{c}$ & $100 \pm 0^{b}$ & $\begin{array}{l}0.318 \pm \\
0.010^{\mathrm{b}}\end{array}$ & $\begin{array}{l}0.286 \pm \\
0.004 \text { cef }\end{array}$ \\
\hline $\begin{array}{l}\text { Kluyveromyces } \\
\text { marxianus }\end{array}$ & DSM 5422 & $\begin{array}{c}21.74 \pm \\
0.89 c\end{array}$ & $\begin{array}{c}2.63 \pm \\
0.17^{\mathrm{a}}\end{array}$ & $0.20 \pm 0.08$ & $80 \pm 2^{c}$ & $100 \pm 0^{\mathrm{b}}$ & $\begin{array}{l}0.322 \pm \\
0.009 b\end{array}$ & $\begin{array}{l}0.302 \pm \\
0.012^{c}\end{array}$ \\
\hline $\begin{array}{l}\text { Kluyveromyces } \\
\text { marxianus }\end{array}$ & DSM 5418 & $\begin{array}{c}18.40 \pm \\
1.43^{\text {be }} \\
\end{array}$ & $\begin{array}{c}3.96 \pm \\
0.01^{\mathrm{a}} \\
\end{array}$ & $0.10 \pm 0.01$ & $82 \pm 1^{c}$ & $100 \pm 0^{b}$ & $\begin{array}{l}0.261 \pm \\
0.022^{\mathrm{ab}} \\
\end{array}$ & $\begin{array}{l}0.256 \pm \\
0.020^{\text {be }}\end{array}$ \\
\hline $\begin{array}{l}\text { Kluyveromyces } \\
\text { marxianus }\end{array}$ & DSM 7239 & $\begin{array}{c}18.39 \pm \\
0.65^{\mathrm{be}}\end{array}$ & $\begin{array}{c}3.41 \pm \\
0.29^{a}\end{array}$ & $5.09 \pm 0$ & $84 \pm 2^{c}$ & $100 \pm 0^{b}$ & $\begin{array}{l}0.253 \pm \\
0.007^{\mathrm{ab}}\end{array}$ & $\begin{array}{l}0.255 \pm \\
0.009 \text { be }\end{array}$ \\
\hline Kluyveromyces lactis & DSM 70799 & $\begin{array}{c}17.90 \pm \\
0.69^{b f}\end{array}$ & $\begin{array}{c}2.27 \pm \\
0.53^{\mathrm{a}}\end{array}$ & $<0.05$ & $80 \pm 1^{c}$ & $100 \pm 0^{b}$ & $\begin{array}{l}0.260 \pm \\
0.009 \mathrm{ab}\end{array}$ & $\begin{array}{l}0.248 \pm \\
0.009 \mathrm{bf}\end{array}$ \\
\hline $\begin{array}{l}\text { Saccharomyces } \\
\text { cerevisiae }\end{array}$ & CECT 1383 & $\begin{array}{c}16.96 \pm \\
1.51^{\mathrm{b}} \\
\end{array}$ & $\begin{array}{c}2.96 \pm \\
0.36^{\mathrm{a}}\end{array}$ & $<0.05$ & $81 \pm 2^{c}$ & $100 \pm 0^{b}$ & $\begin{array}{l}0.248 \pm \\
0.015^{\mathrm{ab}}\end{array}$ & $\begin{array}{c}0.236 \pm \\
0.021^{b}\end{array}$ \\
\hline $\begin{array}{l}\text { Saccharomyces } \\
\text { cerevisiae }\end{array}$ & DSM 70449 & $\begin{array}{l}6.61 \pm \\
2.12^{\mathrm{d}}\end{array}$ & $\begin{array}{l}3.85 \pm \\
2.76^{a}\end{array}$ & $4.08 \pm 5.65$ & $34 \pm 14^{b}$ & $53 \pm 16^{c}$ & $\begin{array}{l}0.240 \pm \\
0.030^{\mathrm{ab}}\end{array}$ & $\begin{array}{l}0.092 \pm \\
0.029 \mathrm{~d}\end{array}$ \\
\hline $\begin{array}{l}\text { Saccharomyces } \\
\text { cerevisiae }\end{array}$ & \begin{tabular}{|l|} 
Ethanol \\
Red®
\end{tabular} & $\begin{array}{c}21.61 \pm \\
1.21 \text { ce } \\
\end{array}$ & $\begin{array}{c}3.10 \pm \\
0.11^{\mathrm{a}}\end{array}$ & $0.11 \pm 0.03$ & $90 \pm 0^{c}$ & $100 \pm 0^{b}$ & $\begin{array}{l}0.284 \pm \\
0.015^{\mathrm{ab}}\end{array}$ & $\begin{array}{l}0.300 \pm \\
0.017^{\mathrm{ce}}\end{array}$ \\
\hline $\begin{array}{l}\text { Saccharomyces } \\
\text { cerevisiae }\end{array}$ & Hércules & $\begin{array}{c}20.11 \pm \\
1.35^{\mathrm{bc}}\end{array}$ & $\begin{array}{c}2.27 \pm \\
0.63^{\mathrm{a}}\end{array}$ & $<0.05$ & $90 \pm 2^{c}$ & $100 \pm 0^{b}$ & $\begin{array}{l}0.266 \pm \\
0.017^{\mathrm{ab}}\end{array}$ & $\begin{array}{l}0.279 \pm \\
0.019 \mathrm{bc}\end{array}$ \\
\hline $\begin{array}{l}\text { Scheffersomyces } \\
\text { stipitis }\end{array}$ & DSM 3651 & $\begin{array}{c}0.20 \pm \\
0.02^{\mathrm{a}}\end{array}$ & $\begin{array}{l}2.81 \pm \\
0.06^{\mathrm{a}}\end{array}$ & $0.11 \pm 0.02$ & $8 \pm 8^{a}$ & $8 \pm 7^{a}$ & $\begin{array}{l}0.204 \pm \\
0.310^{\mathrm{ab}}\end{array}$ & $\begin{array}{c}0.003 \pm \\
0.003^{a}\end{array}$ \\
\hline $\begin{array}{l}\text { Scheffersomyces } \\
\text { stipitis }\end{array}$ & DSM 3652 & $\begin{array}{c}0.19 \pm \\
0.09 \mathrm{a}\end{array}$ & $\begin{array}{l}3.48 \pm \\
0.69^{\mathrm{a}}\end{array}$ & $3.85 \pm 3.40$ & $20 \pm 4^{\mathrm{ab}}$ & $18 \pm 1^{a}$ & $\begin{array}{l}0.011 \pm \\
0.003^{a}\end{array}$ & $\begin{array}{c}0.003 \pm \\
0.001^{\mathrm{a}}\end{array}$ \\
\hline Zymomonas mobilis & DSM 3580 & $\begin{array}{c}16.63 \pm \\
0.39 b\end{array}$ & $\begin{array}{c}4.61 \pm \\
0.01^{\mathrm{a}}\end{array}$ & $\begin{array}{c}13.01 \pm \\
0.34\end{array}$ & $53 \pm 4^{d}$ & $75 \pm 2^{d}$ & $\begin{array}{l}0.384 \pm \\
0.043^{b}\end{array}$ & $\begin{array}{l}0.231 \pm \\
0.005^{b}\end{array}$ \\
\hline
\end{tabular}

The best ethanol concentration of $21.7 \mathrm{~g} / \mathrm{L}$ (obtained by $K$. marxianus DSM 5422) is clearly higher than those reported in literature for the fermentation of similar tomato wastes. Patle and Lal (2007) employed a co-culture of $Z$. mobilis MTCC 92 and Candida tropicalis TERI SH 110 to ferment a tomato waste hydrolysate containing $36 \mathrm{~g} / \mathrm{L}$ sugar, and obtained 14 $\mathrm{g} / \mathrm{L}$ ethanol. Kasavi et al. (2012) fermented untreated tomato peels with S. cerevisiae strains, BC187, L-1374, L-1528, K11 and Y9, but with an extremely low sugar initial concentration (1 $\mathrm{g} / \mathrm{L}$ carbon), which resulted in an ethanol concentration of $0.16-0.27 \mathrm{~g} / \mathrm{L}$ and a sugar consumption of $42.3-54.8 \%$. Lenucci et al. (2013) subjected tomato pomace to enzymatic hydrolysis and obtained a broth with $28.6 \mathrm{~g} / \mathrm{L}$ total sugars, which was fermented by S. cerevisiae strain Cispa 161 to about $10 \mathrm{~g} / \mathrm{L}$ ethanol in $12 \mathrm{~h}$; in addition, they prepared a more concentrated broth with $57 \mathrm{~g} / \mathrm{L}$ total sugars, which yielded $15 \mathrm{~g} / \mathrm{L}$ ethanol in $72 \mathrm{~h}$.

In order to obtain profitable concentrations of ethanol, it is necessary to start the fermentation with a sufficient sugar concentration (Díez-Antolínez et al., 2016, 2018; Olsson and Hahn-Hägerdal, 1996). Because of that, the biomass-to-solvent ratio during the pretreatment has to be increased. The minimum solids concentration for economic ethanol production is about 15\% (Parawira and Tekere, 2011). As mentioned in section 3.1, the biomass ratio of $30 \%$ resulted in a slow enzymatic hydrolysis. Taking into account this problem and the low ethanol titres obtained, tomato pomace does not seem a good feedstock for bioethanol production under the conditions tested in this study.

\section{Conclusions}

Autohydrolysis was successful to pretreat tomato pomace. However, to avoid long treatment times during the enzymatic hydrolysis, solid-to-solvent ratios of up to $20 \%(\mathrm{w} / \mathrm{w})$ are recommended.

Although the ethanol concentrations obtained $(\sim 20$ $\mathrm{g} / \mathrm{L}$ ) are the highest reported, this value is insufficient for industrial exploitation. However, our results indicate that $K$. marxianus, $K$. lactis or $L$. thermotolerans are potential biocatalysts for lignocellulosic biomass hydrolysates containing inhibitory substances.

In contrast, tomato pomace was a suitable feedstock for $A B E l$ fermentation. Before considering the use of this biomass in industrial biorefineries, it would be necessary to optimise fermentation and nutrient conditions to reduce costs. 


\section{Appendix A}

The results of fermentation controls are shown in Table A1 (ABEI) and Table A2 (ethanol).

Declaration of interests: None.

\section{Acknowledgements}

The authors thank Novozymes Denmark and Novozymes China for kindly providing samples of their enzymes. The authors are grateful to Conservas Vegetales de Extremadura SA (CONESA) for generously supplying tomato waste. $\mathrm{MH}-\mathrm{V}$ is supported by a postdoctoral contract (DOC-INIA, grant number DOC 2013-010) funded by INIA and the European Social Fund. Authors thank R. Antón del Río, N. del Castillo Ferreras and G. Sarmiento Martínez for their technical help.

Funding: This work has been funded by FEDER-INIA (Instituto Nacional de Investigación y Tecnología Agraria y Alimentaria), under the Project RTA 201500060-C04-01 (Integral revalorisation of by-products based on their potential uses: energy revalorization).

\section{References}

1. Aramrueang, N., Zicari, S.M., Zhang, R., 2017. Characterization and compositional analysis of agricultural crops and residues for ethanol production in California. Biomass Bioenerg. 105, 288-297.

https://doi.org/10.1016/j.biombioe.2017.07.013.

2. Bahl, H., Gottwald, M., Kuhn, A., Rale, V., Andersch, W., Gottschalk, G., 1986. Nutritional factors affecting the ratio of solvents produced by Clostridium acetobutylicum. Appl. Environ. Microbiol. 52, 169-172. https://aem.asm.org/content/52/1/169.

3. Bellido, C., Bolado, S., Coca, M., Lucas, S., González-Benito, G., García-Cubero, M.T., 2011. Effect of inhibitors formed during wheat straw pretreatment on ethanol fermentation by Pichia stipitis. Bioresour Technol. 102, 10868-10874. https://doi.org/10.1016/j.biortech.2011.08.128.

4. Chen, J., Zidwick, M., Rogers P., 2013. Organic acid and solvent production: Butanol, acetone, and isopropanol; 1,3- and 1,2-propanediol production; and 2,3-butanediol production, in: Rosenberg E., DeLong, E.F., Lory, S., Stackebrandt. E., Thompson F. (Eds.), The Prokaryotes. SpringerVerlag, Berlin Heidelberg, pp. 77-134. http://dx.doi.org/10.1007/978-3-642-31331-

8_386.
5. de Araújo, L.C.A., de Cássia Dias Mendes, T., dos Santos, B.S., da Mota Silveira Filho, V., de Souza Lima, G:M., de Araújo, J.M., dos Santos Correia, M.T., de Oliveira, M.B.M., Morais Júnior, M.A., da Silva, M.V., 2018. Molecular identification and physiological characterization of Zymomonas mobilis strains from fuel-ethanol production plants in north-east Brazil. Lett. Appl. Microbiol. 67, 54-63. http://dx.doi.org/10.1111/lam.12888.

6. del Campo, I., Alegría, I., Zazpe, M., Echeverría, M., Echeverría, I., 2006. Diluted acid hydrolysis pretreatment of agri-food wastes for bioethanol production. Ind. Crops Prod. 24, 214-221. http://dx.doi.org/10.1016/j.indcrop.2006.06.014.

7. del Valle, M., Cámara, M., Torija, M.E., 2006. Chemical characterization of tomato pomace. J. Sci. Food Agric. 86, 1232-1236. https://doi.org/10.1002/jsfa.2474.

8. Diaz, A.B., Blandino, A., Caro, I., 2018. Value added products from fermentation of sugars derived from agro-food residues. Trends Food Sci. Tech. 71, 52-64. https://doi.org/10.1016/ j.tifs.2017.10.016.

9. Díaz, A.l., Laca, A., Laca, A., Díaz, M., 2017. Treatment of supermarket vegetable wastes to be used as alternative substrates in bioprocesses. Waste Manag. 67, 59-66. http://dx.doi.org/10.1016/j.wasman.2017.05.018.

10. Díez-Antolínez, R., Hijosa-Valsero, M., PaniaguaGarcía, A.l., Garita-Cambronero, J., Gómez, X., 2018. Yeast screening and cell immobilization on inert supports for ethanol production from cheese whey permeate with high lactose loads. PLOS ONE 13(12), e0210002. https://doi.org/10.1371/journal.pone.0210002.

11. Díez-Antolínez, R., Hijosa-Valsero, M., PaniaguaGarcía, A.I., Gómez, X., 2016. Very-high-gravity fermentation of non-supplemented cheese whey permeate by immobilized Kluyveromyces marxianus. Chemical Engineering Transactions 49, 529-534. https://doi.org/10.3303/CET1649089.

12. du Preez, J.C., Bosch, M., Prior, B.A., 1986. The fermentation of hexose and pentose sugars by Candida shehatae and Pichia stipitis. Appl. Microbiol. Biotechnol. 23, 228-233. https://doi.org/10.1007/BF00261920.

13. Eurostat., 2019. Crop production in EU standard humidity.

https://ec.europa.eu/eurostat/data/database. Accessed on 16 January 2019. 
14. FAO., 2019. FAOSTAT, Production, Crops. http://www.fao.org/faostat/en/\#data. Accessed on 16 January 2019.

15. Fritsch, C., Staebler, A., Happel, A., CuberoMárquez, M.A., Aguiló-Aguayo, I., Abadias, M., Gallur, M., Cigognini, I.M., Montanari, A., López, M.J., Suárez-Estrella, F., Brunton, N., Luengo, E., Sisti, L., Ferri, M., Belotti, G., 2017. Processing, valorization and application of bio-waste derived compounds from potato, tomato, olive and cereals: A review. Sustainability 9, 1492. http://dx.doi.org/10.3390/su9081492.

16. Hassan, S.S., Williams, G.A., Jaiswal, A.K., 2019. Lignocellulosic biorefineries in Europe: Current state and prospects. Trends Biotechnol. 37, 231234.

https://doi.org/10.1016/j.tibtech.2018.07.002.

17. Hegde, S., Lodge, J., Trabold, T., 2018. Characteristics of food processing wastes and their use in sustainable alcohol production. Renew. Sustain. Energy Rev. 81, 510-523. https://doi.org/10.1016/j.rser.2017.07.012.

18. Hijosa-Valsero, M., Paniagua-García, A.l., DíezAntolínez, R., 2017. Biobutanol production from apple pomace: the importance of pretreatment methods on the fermentability of lignocellulosic agro-food wastes. Appl. Microbiol. Biotechnol. 101, 8041-8052. https://doi.org/10.1007/s00253017-8522-z.

19. Hijosa-Valsero, M., Garita-Cambronero, J., Paniagua-García, A.l., Díez-Antolínez, R., 2018a. Biobutanol production from coffee silverskin. Microb. Cell Fact. 17, 154. https://doi.org/10.1186/s12934-018-1002-z.

20. Hijosa-Valsero, M., Paniagua-García, A.l., DíezAntolínez, R., 2018b. Industrial potato peel as a feedstock for biobutanol production. New Biotechnol. 46, 54-60. https://doi.org/10.1016/j.nbt.2018.07.002.

21. Huzir, N.M., Aziz, M.M.A., Ismail, S.B., Abdullah, B., Mahmood, N.A.N., Umor, N.A., Muhammad, S.A.F.S., 2018. Agro-industrial waste to biobutanol production: Eco-friendly biofuels for next generation. Renew. Sust. Energ. Rev. 94, 476-485. https://doi.org/10.1016/j.rser.2018.06.036.

22. Kasavi, C., Finore, I., Lama, L., Nicolaus, B., Oliver, S.G., Oner, E.T., Kirdar, B., 2012. Evaluation of industrial Saccharomyces cerevisiae strains for ethanol production from biomass. Biomass and Bioenergy. 230-238. http://dx.doi.org/10.1016/j.biombioe.2012.06.013.
23. Kaur, D., Wani, A.A., Oberoi, D.P.S., Sogi, D.S., 2008. Effect of extraction conditions on lycopene extractions from tomato processing waste skin using response surface methodology. Food Chem. 108, 711-718. https://doi.org/10.1016/j.foodchem.2007.11.002.

24. Kurtzman, C.P., 2011. Scheffersomyces Kurtzman \& M. Suzuki (2010). The Yeasts, a taxonomic study (Fifth Edition). , in: Kurtzman, C., Fell, J.W., Boekhout, T. (Eds.), The Yeasts, a taxonomic study (Fifth Edition). Elsevier Science, pp. 773-777. https://doi.org/10.1016/B978-0-444-521491.00061-6.

25. Lachance, M.A., 2011. Kluyveromyces van der Walt (1971), in: Kurtzman, C., Fell, J.W., Boekhout, T. (Eds.), The Yeasts, a taxonomic study (Fifth Edition). Elsevier Science, pp. 733-746. https://doi.org/10.1016/B978-0-444-521491.00061-6.

26. Lachance, M.A., Kurtzman, C.P., 2011. Lachancea Kurtzman (2003). The Yeasts, a taxonomic study (Fifth Edition). , in: Kurtzman, C., Fell, J.W., Boekhout, T. (Eds.), The Yeasts, a taxonomic study (Fifth Edition). Elsevier Science, pp. 511-519. https://doi.org/10.1016/B978-0-444-521491.00061-6.

27. Lane, M.M., Burke, N., Karreman, R., Wolfe, K.H., O'Byrne, C.P., Morrissey, J.P., 2011. Physiological and metabolic diversity in the yeast Kluyveromyces marxianus. Antonie van Leeuwenhoek. 100, 507-519. 10.1007/s10482011-9606-x.

28. Lenucci, M.S., Durante, M., Montefusco, A., Dalessandro, G., Piro, G., 2013. Possible use of the carbohydrates present in tomato pomace and in byproducts of the supercritical carbon dioxide lycopene extraction process as biomass for bioethanol production. J. Agric. Food Chem. 61, 3683-3692. http://dx.doi.org/10.1021/jf4005059.

29. Olofsson, K., Bertilsson, M., Lidén, G., 2008. A short review on SSF - an interesting process option for ethanol production from lignocellulosic feedstocks. Biotechnology for Biofuels 1, 7. https://doi.org/10.1186/1754-68341-7.

30. Olsson, L., Hahn-Hägerdal, B., 1996. Fermentation of lignocellulosic hydrolysates for ethanol production. Enzyme and Microbial Technology 18, 312-331.

31. Otles, S., Kartal, C., 2018. Food waste valorization, in: Galanakis, C.M. (Eds.), Sustainable Food Systems from Agriculture to Industry. Academic 
Press, London, pp. 371-399.

https://doi.org/10.1016/B978-0-12-811935-

8.00011-1.

32. Paniagua-García, A.l., Hijosa-Valsero, M., DíezAntolínez, R., Sánchez, M.E., Coca, M., 2018. Enzymatic hydrolysis and detoxification of lignocellulosic biomass are not always necessary for ABE fermentation: The case of Panicum virgatum. Biomass Bioenerg. 116, 131-139. https://doi.org/10.1016/j.biombioe.2018.06.006.

33. Parawira, W., Tekere, M., 2011. Biotechnological strategies to overcome inhibitors in lignocellulose hydrolysates for ethanol production: review. Crit. Rev. Biotechnol. 31, 20-31. http://dx.doi.org/10.3109/07388551003757816.

34. Patle, S., Lal, B., 2007. Ethanol production from hydrolysed agricultural wastes using mixed culture of Zymomonas mobilis and Candida tropicalis. Biotechnol. Lett. 29, 1839-1843. http://dx.doi.org/10.1007/s10529-007-9493-4.

35. Pentjuss, A., Stalidzans, E., Liepins, J., Kokina, A., Martynova, J.,Zikmanis, P., Mozga, I., Scherbaka, R., Hartman, H., Poolman, M.G., Fell, D.A., Vigants, A., 2017. Model based biotechnological potential analysis of Kluyveromyces marxianus central metabolism. J. Ind. Microbiol. Biotechnol. 44, 1177-1190. 10.1007/s10295-017-1946-8.

36. Ravindran, R., Jaiswal, A.K., 2016. Exploitation of food industry waste for high-value products. Trends Biotechnol. 34, 58-69. http://dx.doi.org/10.1016/j.tibtech.2015.10.008.

37. Rodrussamee, N., Lertwattanasakul, N., Hirata, K., Suprayogi, S., Kosaka, T., Yamada, M., 2011. Growth and ethanol fermentation ability on hexose and pentose sugars and glucose effect under various conditions in thermotolerant yeast Kluyveromyces marxianus. Appl. Microbiol. Biotechnol. 90, 1573-1586. 10.1007/s00253-0113218-2.

38. Scoma, A., Rebecchi, S., Bertin, L., Fava, F., 2016. High impact biowastes from South European agro-industries as feedstock for secondgeneration biorefineries. Crit. Rev. Biotechnol. 36, 175-89. https://doi.org/10.3109/07388551.2014.947238.

39. Shrestha, N., Fogg, A., Wilder, J., Franco, D., Komisar, S., Gadhamshetty, V., 2016. Electricity generation from defective tomatoes. Bioelectrochemistry 112, 67-76. https://doi.org/10.1016/j.bioelechem.2016.07.005.

40. Silbir, S., Dagbagli, S., Yegin, S., Baysal, T., Goksungur, Y., 2014. Levan production by
Zymomonas mobilis in batch and continuous fermentation systems. Carbohydrate Polymers, 99, 454-461.

https://doi.org/10.1016/j.carbpol.2013.08.031.

41. Silveira, M., Jonas, R., 2002. The biotechnological production of sorbitol. Appl. Microbiol. Biotechnol. 59, 400-408. https://doi.org/10.1007/s00253-002-1046-0.

42. Singh, A., Kuila, A., Adak, S., Bishai, M., anerjee, R., 2012. Utilization of Vegetable Wastes for Bioenergy Generation. Agric. Res. 1, 213-222. https://doi.org/10.1007/s40003-012-0030-x.

43. Sprenger, G.A., 1996. Carbohydrate metabolism in Zymomonas mobilis: a catabolic highway with some scenic routes. FEMS Microbiol. Lett. 145, 301-307. https://doi.org/10.1016/S03781097(96)00396-5.

44. Tommonaro, G., Poli, A., De Rosa, S., Nicolaus, B., 2008. Tomato derived polysaccharides for biotechnological applications: Chemical and biological approaches. Molecules. 13, 1384-1398. https://doi.org/10.3390/molecules13061384.

45. van Maris, A.J.A., Abbott, D.A., Bellissimi, E., van den Brink, J., Kuyper, M., Luttik, M.A.H., Wisselink, H.W., Scheffers, W.A., van Dijken, J.P., Pronk, J.T., 2006. Alcoholic fermentation of carbon sources in biomass hydrolysates by Saccharomyces cerevisiae: current status. Antonie van Leeuwenhoek. 90, 391-418. 10.1007/s10482-0069085-7.

46. Vaughan-Martini, A., Martini, A., 2011. Saccharomyces Meyen ex Reess (1870), in: Kurtzman, C., Fell, J.W., Boekhout, T. (Eds.), The Yeasts, a taxonomic study (Fifth Edition). Elsevier Science, pp. 733-746. https://doi.org/10.1016/B978-0-444-521491.00061-6.

47. Xin, F., Chen, T., Jiang, Y., Dong, W., Zhang, W., Zhang, M., Wu, H., Ma, J., Jiang, M., 2017. Strategies for improved isopropanol-butanol production by a Clostridium strain from glucose and hemicellulose through consolidated bioprocessing. Biotechnol. Biofuels. 10, 118. https://doi.org/10.1186/s13068-017-0805-1.

48. Yerushalmi, L., Volesky, B., 1987. Culture conditions for growth and solvent biosynthesis by a modified Clostridium acetobutylicum. Appl. Microbiol. Biotechnol. 25, 513-520. https://doi.org/10.1007/BF00252009. 


\section{APPENDIX}

Table A1. Acetone-butanol-ethanol-isopropanol (ABEI) fermentation of control solutions containing glucose, xylose and nutrients.

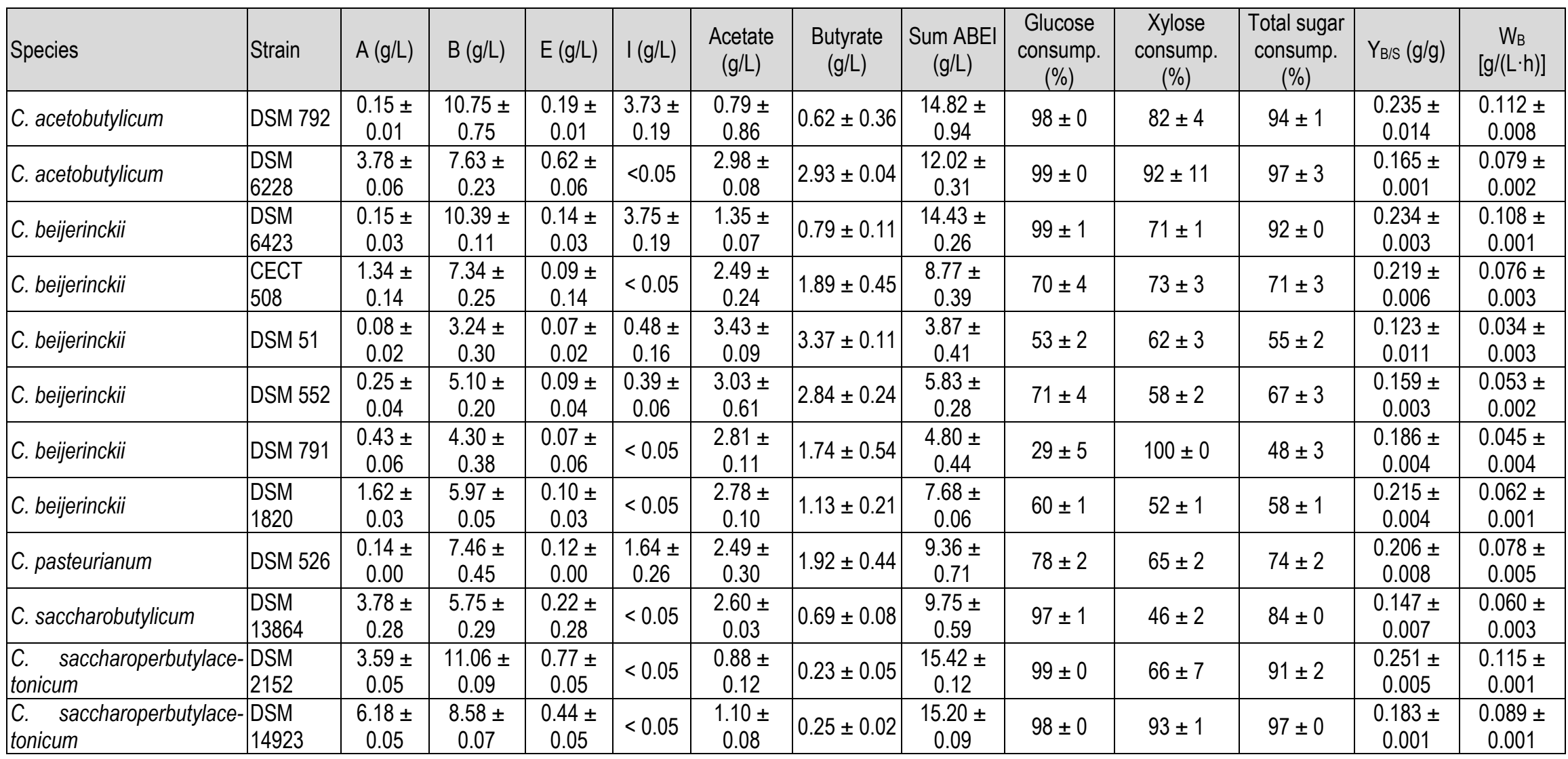


Table A2. Alcoholic fermentation of control solutions containing glucose, xylose and nutrients.

\begin{tabular}{|c|c|c|c|c|c|c|c|c|c|}
\hline Species & Strain & Ethanol $(\mathrm{g} / \mathrm{L})$ & Acetic acid $(\mathrm{g} / \mathrm{L})$ & Lactic acid (g/L) & $\begin{array}{c}\text { Glucose } \\
\text { consumption (\%) }\end{array}$ & $\begin{array}{c}\text { Xylose } \\
\text { consumption (\%) }\end{array}$ & $\begin{array}{c}\text { Total sugar } \\
\text { consumption (\%) }\end{array}$ & $Y_{E / S}(g / g)$ & $W_{E}[g /(L \cdot h)]$ \\
\hline $\begin{array}{l}\text { Lachancea } \\
\text { thermotolerans }\end{array}$ & DSM 3434 & $19.91 \pm 0.20$ & $0.00 \pm 0.00$ & $<0.05$ & $100 \pm 0$ & $57 \pm 4$ & $85 \pm 1$ & $\begin{array}{c}0.303 \pm \\
0.004\end{array}$ & $\begin{array}{c}0.276 \pm \\
0.003\end{array}$ \\
\hline Kluyveromyces marxianus & DSM 5422 & $17.40 \pm 0.09$ & $3.25 \pm 0.11$ & $<0.05$ & $100 \pm 0$ & $38 \pm 1$ & $82 \pm 0$ & $\begin{array}{c}0.269 \pm \\
0.001\end{array}$ & $\begin{array}{c}0.242 \pm \\
0.001\end{array}$ \\
\hline Kluyveromyces marxianus & DSM 5418 & $15.25 \pm 0.27$ & $4.56 \pm 0.22$ & $<0.05$ & $100 \pm 0$ & $47 \pm 0$ & $81 \pm 0$ & $\begin{array}{c}0.242 \pm \\
0.005\end{array}$ & $\begin{array}{c}0.212 \pm \\
0.004\end{array}$ \\
\hline Kluyveromyces marxianus & DSM 7239 & $15.69 \pm 0.50$ & $4.39 \pm 0.34$ & $<0.05$ & $100 \pm 0$ & $49 \pm 0$ & $82 \pm 0$ & $\begin{array}{c}0.247 \pm \\
0.008\end{array}$ & $\begin{array}{c}0.218 \pm \\
0.007\end{array}$ \\
\hline Kluyveromyces lactis & DSM 70799 & $13.15 \pm 0.56$ & $0.00 \pm 0.00$ & $<0.05$ & $90 \pm 2$ & $32 \pm 0$ & $70 \pm 2$ & $\begin{array}{c}0.243 \pm \\
0.008\end{array}$ & $\begin{array}{c}0.183 \pm \\
0.008 \\
\end{array}$ \\
\hline $\begin{array}{l}\text { Saccharomyces } \\
\text { cerevisiae }\end{array}$ & CECT 1383 & $17.42 \pm 0.56$ & $1.40 \pm 0.03$ & $<0.05$ & $100 \pm 0$ & $26 \pm 0$ & $79 \pm 0$ & $\begin{array}{c}0.281 \pm \\
0.009\end{array}$ & $\begin{array}{c}0.242 \pm \\
0.008\end{array}$ \\
\hline $\begin{array}{l}\text { Saccharomyces } \\
\text { cerevisiae }\end{array}$ & DSM 70449 & $14.31 \pm 1.64$ & $0.74 \pm 0.09$ & $<0.05$ & $88 \pm 6$ & $30 \pm 3$ & $68 \pm 5$ & $\begin{array}{c}0.273 \pm \\
0.023\end{array}$ & $\begin{array}{c}0.199 \pm \\
0.023\end{array}$ \\
\hline $\begin{array}{l}\text { Saccharomyces } \\
\text { cerevisiae }\end{array}$ & Ethanol Red ${ }^{\circledR}$ & $16.08 \pm 0.16$ & $5.49 \pm 0.22$ & $<0.05$ & $100 \pm 0$ & $26 \pm 0$ & $79 \pm 0$ & $\begin{array}{c}0.260 \pm \\
0.002 \\
\end{array}$ & $\begin{array}{c}0.223 \pm \\
0.002 \\
\end{array}$ \\
\hline $\begin{array}{l}\text { Saccharomyces } \\
\text { cerevisiae }\end{array}$ & Hércules & $17.45 \pm 0.34$ & $0.13 \pm 0.06$ & $<0.05$ & $100 \pm 0$ & $37 \pm 0$ & $82 \pm 0$ & $\begin{array}{c}0.271 \pm \\
0.005\end{array}$ & $\begin{array}{c}0.242 \pm \\
0.005\end{array}$ \\
\hline Scheffersomyces stipitis & DSM 3651 & $18.36 \pm 0.37$ & $0.79 \pm 0.02$ & $<0.05$ & $98 \pm 2$ & $11 \pm 2$ & $73 \pm 2$ & $\begin{array}{c}0.321 \pm \\
0.002\end{array}$ & $\begin{array}{c}0.255 \pm \\
0.005\end{array}$ \\
\hline Scheffersomyces stipitis & DSM 3652 & $18.02 \pm 0.21$ & $0.67 \pm 0.01$ & $<0.05$ & $100 \pm 0$ & $36 \pm 2$ & $82 \pm 1$ & $\begin{array}{c}0.281 \pm \\
0.002 \\
\end{array}$ & $\begin{array}{c}0.250 \pm \\
0.003\end{array}$ \\
\hline Zymomonas mobilis & DSM 3580 & $27.48 \pm 0.20$ & $0.45 \pm 0.04$ & $0.23 \pm 0.07$ & $100 \pm 0$ & $30 \pm 0$ & $76 \pm 0$ & $\begin{array}{c}0.459 \pm \\
0.009\end{array}$ & $\begin{array}{c}0.382 \pm \\
0.003 \\
\end{array}$ \\
\hline
\end{tabular}

